

\title{
EFEKTIFITAS TERAPI MASSAGE TERHADAP CEDERA OLAHRAGA NYERI TUMIT DAN NYERI OTOT TIBIALIS PADA ATLET FUTSAL SMPN 18 KOTA BENGKULU
}

\author{
Dibyo Ika Pratama ${ }^{1}$, Sugiyanto ${ }^{2}$, Santun Sihombing ${ }^{3}$ \\ ${ }^{123}$ Pendidikan Jasmani, FKIP Universitas Bengkulu, Bengkulu, Indonesia
}

Info Artikel

Sejarah Artikel:

Diterima Oktober 2020

Direvisi Oktober 2020

Diterima Oktober 2020

Tersedia online Oktober 2020

Kata kunci:

Terapi Massage, Nyeri Tumit, \& Nyeri Otot Tibialis

\begin{abstract}
Abstrak
Didalam olahraga futsal akan sering terjadinya body contact dan rawan akan terjadinya cedera. Futsal merupakan olahraga yang berintensitas tinggi yang di tandai dengan adanya aktivitas berlari secara berulang-ulang dengan waktu yang relatif lama sehingga beresiko cedera pada kaki. Gangguan nyeri tumit dan nyeri otot tibialis banyak terjadi pada pemain futsal. Tujuan penelitian ini adalah untuk mengetahui: a) efektifitas terapi massage terhadap cedera olahraga nyeri tumit pada atlet futsal SMPN 18 Kota Bengkulu dan b) efektifitas terapi massage terhadap cedera olahraga nyeri otot tibialis pada atlet futsal SMPN 18 Kota Bengkulu. Penelitian ini merupakan penelitian lapangan (field research) dengan pendekatan kualitatif. Sumber data dalam penelitian ini adalah guru penjaskes dan semua atlet futsal SMPN 18 Kota Bengkulu yang mengalami cedera olahraga nyeri tumit dan nyeri otot tibialis. Teknik pengumpulan data dilakukan melalui teknik wawancara, observasi dan dokumentasi. Data yang telah diperoleh dianalisis dengan mnggunakan teori Creswell (2014). Hasil penelitian menunjukan bahwa terapi massage sangat efektif terhadap cedera olahraga nyeri tumit dan nyeri otot tibialis pada atlet futsal SMPN 18 Kota Bengkulu.
\end{abstract}

\footnotetext{
Abstract

In futsal, there will often be body contact and injury prone. Futsal is a high-intensity sport that is characterized by the activity of running repeatedly with a relatively long time so that the risk of injury to the feet. Heel pain and tibial muscle pain are common in futsal players. The purpose of this study was to determine: a) the effectiveness of massage therapy for heel pain sports injuries in futsal athletes of SMPN 18 Bengkulu City and b) the effectiveness of massage therapy for tibial muscle pain sports injuries in futsal athletes of SMPN 18 Bengkulu City. This research is a field research with a qualitative approach. The data source in this study
} 
is the physical education teacher and all futsal athletes of SMPN 18 Bengkulu City who suffer from sports injuries of heel pain and tibial muscle pain. The technique of collecting data is done through interviews, observation and documentation. The data obtained were analyzed using Creswell's theory (2014). The results showed that massage therapy was very effective against sports injuries of heel pain and tibial muscle pain in futsal athletes of SMPN 18 Bengkulu City.

Alamat yang sesuai: Jl. Raden Fatah No. 100 Kota Bengkulu Email yang sesuai: dibyo_pratama@yahoo.com
ISSN 2746-055X (online)

DOI : $10.33369 /$ gymnastics.v1i2.12805

\section{PENDAHULUAN}

Olahraga futsal merupakan adalah olahraga bersifat kelompok yang sering terjadi adanya body contact dan rawan akan cedera. Cedera yang sering dialami oleh pemain futsal sebagian besar terjadi pada ektremitas bawah yang meliputi 1 lutut dan ankle. Cedera yang dialami oleh pemain futsal menunjukan paling tinggi pada bagian ektremitas bawah $47.18 \%$, cedera pada bagian ektremitas atas $19.01 \%$, cedera pada bagian togok $18.31 \%$, dan pada bagian kepala sebanyak 15.49\% (Wahyu 2013: 78). Sebuah hasil riset injury risk of playing football in Futsal World Cups terdiagnosis cedera yang sering pada bagian kaki bawah yaitu cedera pada ankle sprain $9.7 \%$, dan groin strain $7.9 \%$.

Cedera merupakan salah satu hambatan bagi olahragawan atau atlet dalam meraih prestasi olahraga. Faktor terjadinya cedera yang dialami atlet diantaranya karena riwayat cedera sebelumnya, kelelahan otot, dan gerakan fungsional kaki yang tidak baik dikarenakan kurangnya pemanasan (warming up) dan peregangan (streching) saat melakukan olahraga. Cedera pada pemain futsal bisa terjadi pada saat kontak fisik dengan lawan, terlalu berat latihan yang diberikan (overtraining), kesalahan teknik menendang bola, terjatuh pada saat kontak fisik.

Cedera olahraga nyeri tumit dan nyeri otot tibialis termasuk dalam cedera tingkat 2 (cedera sedang). Cedera tersebut masuk dalam anatomi kaki dimana kaki merupakan bagian tubuh mulai dari pergelangan kaki sampai jari-jari kaki yang dimana dilengkapi dengan jaringan lunak seperti tendon yang merupakan bantalan untuk menahan berat badan tubuh yang menekan pada daerah tersebut.

Penanganan cedera banyak macam cara yaitu dengan pengobatan medis maupun non medis, pengobatan medis meliputi terapi rehabilitasi olahraga dengan menggunakan penanganan pengobatan alternatif dan olahraga terapi sebagai pilihan untuk penyembuhan pasca cedera yang dialami atlet tersebut yaitu terapi herbal, terapi massage, thermotherphy, coldtherphy, hydrotheraphy, manual theraphy, terapi yoga, exercise therapy, dan lain lain.

Terapi massage merupakan salah satu cara untuk atlet melakukan recovery setelah latihan atau pertandingan. Berbagai macam terapi massage yang ditawarkan diantaranya shiatsu, tsubo, akupuntur, sport massage, deep tissue massage, frirage, dan masih banyak yang lainnya. Masing-masing dari teknik 
massage di atas mempunyai teknik manipulasi yang berbeda-beda khususnya pada massage. Manipuasi massage ada 4 cara yaitu gabungan teknik efflurage dan friction dilakukan secara bersamaan menggunakan ibu jari untuk memijat, traction (tarikan), dan reposition (reposisi) yang bertujuan untuk mengurangi ketegangan otot dan pemulihan cedera.

Berdasarkan hasil pengamatan awal yang peneliti lakukan pada tanggal 26 Agustus 2019 saat tim futsal SMPN 18 Kota Bengkulu melakukan latihan di lapangan dapat diketahui sebagai berikut:

1. Atlet futsal SMPN 18 Kota Bengkulu mengalami rasa nyeri pada tumit;

2. Atlet futsal SMPN 18 Kota Bengkulu mengalami rasa nyeri pada otot bagian tibialis;

3. Belum adanya perlakuan terapi massage pada pemain futsal SMPN 18 Kota Bengkulu yang baik dan benar.

Oleh sebab itu, maka tujuan penelitian ini adalah untuk mengetahui sejauh mana efektifitas terapi massage terhadap cedera olahraga nyeri tumit dan nyeri otot tibialis pada atlet futsal SMPN 18 Kota Bengkulu.

\section{METODE}

Penelitian ini menggunakan pendekatan penelitian kualitatif. Menurut Sugiyono (2009: 14), penelitian kualitatif adalah penelitian yang bermaksud untuk memahami fenomena tentang apa yang dialami oleh subjek penelitian misalnya perilaku, persepsi, motivasi, tindakan, dan lain-lain secara holistik dan dengan cara deskripsi dalam bentuk kata-kata dan bahasa, pada suatu konteks khusus yang alamiah dan dengan memanfaatkan berbagai metode ilmiah.
Data dikumpulkan melalui teknik wawancara, observasi, dan dokumentasi. Informan yang telah diwawancarai dalam penelitian ini ialah 13 orang informan yakni: 1 orang kepala sekolah, 1 orang guru penjas, dan 11 orang atlet futsal SMPN 18 Kota Bengkulu.

Teknik analisis data yang digunakan mengacu pada teori Creswell (2014: 126), yakni: pengumpulan data, reduksi data, penyajian data, dan penarikan kesimpulan. Sedangkan teknik keabsahan data menggunakan triangulasi metode dan triangulasi data.

\section{HASIL}

Penelitian ini dilakukan pada tanggal 23 Maret 2020 sampai tanggal 24 Mei 2020 untuk mengetahui efektifitas terapi massage terhadap cedera olahraga nyeri tumit dan nyeri otot tibialis pada atlet futsal SMPN 18 Kota Bengkulu. Terapi massage yang dimaksud dalam penelitian ini adalah pemberian manipulasi massage pada bagian otot penyokong sendi ankle di mulai dari punggung kaki, tungkai bawah, dan di akhiri pijatan di daerah sendi ankle dengan repetisi 3-5 kali pijatan dan dilakukan dalam waktu 15 menit. Setelah itu dilakukan traksi dan reposisi untuk mengembalikan sendi yang bergeser. Penelitian ini dilakukan terhadap 11 orang atlet futsal yang mengalami cedera nyeri tumit dan mengalami cedera nyeri otot tibialis.

Setelah memberikan perlakuan terapi massage untuk mengatasi cedera nyeri tumit dan nyeri otot tibialis yang sering dialami oleh atlet futsal SMPN 18 Kota Bengkulu, peneliti melakukan wawancara dengan beberapa narasumber mengenai keefektifan terapi massage tersebut terhadap penurunan rasa nyeri tumit dan nyeri otot tibialis. Berdasarkan hasil wawancara dengan Bapak Dedi 
Sapriyanto, S.Pd selaku guru penjaskes di SMPN 18 Kota Bengkulu yang menjelaskan sebagai berikut :

"Terapi massage sangat efektif untuk mengurangi rasa nyeri yang dialami oleh atlet futsal SMPN 18 Kota Bengkulu, khususnya nyeri tumit dan nyeri otot tibialis." (Dedi Sapriyanto, S.Pd, Wawancara, 14 Mei 2020).

Selain wawancara dengan guru
penjas di atas, peneliti juga mewawancarai beberapa atlet futsal di SMPN 18 Kota Bengkulu. Salah satunya ialah Ahmad Fachrul Zaky, ia menjelaskan sebagai berikut :

"Terapi massage sangat efektif bagi pemulihan cedera tumit yang dialami oleh atlet futsal di SMPN 18 Kota Bengkulu." (Ahmad Fachrul Zaky, Wawancara, 14 Mei 2020).

Hal senada juga diungkapkan oleh atlet futsal SMPN 18 Kota Bengkulu lainnya, yakni Nadsir Abdul Jabar, yang mengungkapkan sebagai berikut:

"Terapi massage ini sangat bagus sekali, apabila atlet futsal SMPN 18 Kota Bengkulu mengalami cedera otot tibilais, setelah diterapi maka cederanya jauh berkurang. Menurut mereka terapi massage perlu diterapkan terus secara berkelanjutan." (Nadsir Abdul Jabar, Wawancara, 21 Mei 2020).

Kemudian diperkuat lagi oleh pernyataan salah seorang atlet futsal SMPN 18 Kota Bengkulu lainnya, yakni M. Hafiz, yang mengatakan sebagai berikut :

"Atlet futsal SMPN 18 Kota Bengkulu merasa bersyukur cedera tumit dan otot menjadi menjadi sembuh setelah diterapi massage. Menurut mereka terapi massage sangat efektif." (M. Hafiz, Wawancara, 21 Mei 2020).
Hal serupa juga diungkapkan oleh atlet futsal di SMPN 18 Kota Bengkulu lainnya, yakni Ilham Habibi yang menjelaskan sebagai berikut :

"Peneliti mengadakan terapi massage bagi atlet futsal SMPN 18 Kota Bengkulu yang cedera terutama untuk cedera tumit dan cedera otot tibialis dan hasilnya langsung kurang rasa nyerinya." (Ilham Habibi, Wawancara, 21 Mei 2020).

Berdasarkan hasil wawancara di atas, maka dapat diperoleh suatu kesimpulan sebagai berikut :

1. Terapi massage sangat efektif terhadap cedera olahraga nyeri tumit pada atlet futsal SMPN 18 Kota Bengkulu; dan

2. Terapi massage sangat efektif terhadap cedera olahraga nyeri otot tibialis pada atlet futsal SMPN 18 Kota Bengkulu.

\section{DISKUSI}

Berdasarkan hasil analisis data penelitian perlakuan terapi massage cedera olahraga yaitu massage sangat efektif terhadap penurunan rasa nyeri pada tumit. Secara fisiologis, terapi massage terbukti dapat menurunkan denyut jantung, meningkatkan tekanan darah, meningkatkan sirkulasi darah dan limpa, mengurangi ketegangan otot, dan meningkatkan ruang gerak sendi serta mengurangi rasa nyeri (Arofah, 2010:116).

Pemberian treatment massage pada atlet futsal dapat mengurangi rasa nyeri pada tumit karena manipulasi efflurage dan friction dalam terapi massage akan membantu proses untuk menghancurkan myoglosis yaitu timbunan dari sisa-sisa pembakaran pada otot yang menyebabkan pengerasan 
serabut otot sehingga mengakibatkan timbulnya rasa nyeri (Yulianti, 2015: 22).

Selanjutnya, berdasarkan hasil analisis data hasil penelitian diketahui bahwa perlakuan terapi massage cedera olahraga yaitu massage sangat efektif terhadap penurunan rasa nyeri pada otot tibialis pada atlet futsal SMPN 18 Kota Bengkulu. Terapi massage merupakan salah satu perawatan cedera dengan menggunakan sentuhan untuk merangsang produksi bahan kimia tertentu dalam sistem kekebalan yang mendorong penyembuhan. Massage dapat menghancurkan tumbukan asam laktat yang terakumulasi selama latihan sehingga otot menjadi relaks, meningkatkan sirkulasi darah dan getah bening, meregangkan sendi, serta meredakan rasa nyeri (Kozier, 2018: 284). Pemberian manipuasi massage yaitu gabungan antara gerusan (friction) dan gosokan (efflurage) yang bertujuan untuk memperlancar peredaran darah, merangsang serabut-serabut saraf otot agar relaks, meningkatkan sistem peredaran darah dan melancarkannya, serta mengurangi rasa nyeri dan mempercepat proses regenerasi (Graha, 2012: 21).

Mekanisme terapi massage
terhadap penurunan nyeri yaitu Gate
Control teori dimana teori ini
menjelaskan bahwa rasa nyeri dianggap dapat merangsang serat saraf yang lebih pendek dan kurang terisolasi sehingga sinyal rasa nyeri terhambat untuk sampai ke otak dibandingkan sinyal tekanan yang dibawa oleh serat saraf yang lebih banyak mielin karena mampu mengirimkan rangsangan tekanan lebih cepat dari rangsangan rasa nyeri yang bisa ditransmisikan (Berman, 2015: 1091). Terapi massage mengaktifkan serat berdiameter besar $(A \beta)$, menghambat pesan rasa nyeri yang dibawa oleh serat yang lebih kecil (serat $\mathrm{A} \delta$ dan $\mathrm{C}$ ) ke otak (Champaneri, 2014: 72). Sinyal tekanan dari massage ditransmisikan lebih cepat agar sinyal rasa nyeri tertutup (Kamali, 2014: 479)

\section{KESIMPULAN}

Berdasarkan hasil penelitian yang diperoleh dengan analisis data, maka dapat disimpulkan bahwa sebagai berikut:

1. Terapi massage sangat efektif terhadap cedera olahraga nyeri tumit pada atlet futsal SMPN 18 Kota Bengkulu; dan

2. Terapi massage sangat efektif terhadap cedera olahraga nyeri otot tibialis pada atlet futsal SMPN 18 Kota Bengkulu.

\section{PENGAKUAN}

1. Bagi pelatih, harus mampu menjadi fasilitator bagi atlet untuk dapat meningkatkan kemampuan dan keterampilan secara kompleks sehingga tidak mudah mengalami cedera.

2. Bagi kepala sekolah, harus mampu memberikan fasilitas dan mendukung kegiatan latihan agar atlet dapat meningkatkan kemampuan sehingga tidak mudah cedera.

3. Bagi peneliti selanjutnya agar melakukan kontrol terhadap faktorfaktor yang dapat mempengaruhi latihan dan proses penelitian.

\section{REFERENSI}

Amin, I., \& Moroz, A. (2017). Medial tibial stress syindrome (shin spints). New York: Earlbaum.

Anggoro, A.W., (2014). Penatalaksanaan fisioterapi pada kasus Myalgia (tibialis anterior) Sinistra di RST. dr. Soedjono Magelang. Naskah Publikasi Universitas Muhamadiyah Surakarta, pp. 1-10. 
Arikunto, S. (2006). Prosedur Penelitian: Suatu Pendekatan Praktis. Jakarta: Rineka Cipta.

Baofu, P. (2013). The Future of Post-Human Sports: Towards A New Theory of Training and Winning. New Castle: Cambridge Scholars Publishing.

Creswell, J. W. (2014). Research Design: Pendekatan Kualitatif, Kuantitatif dan Mixed. Yogyakarta: Pustaka Pelajar.

Fondy. T. (2016). Sport massage panduan praktis merawat dan mereposisi cedera tubuh. Jakarta: PT Gramedia Pustaka Utama.

Ginting, S. S. (2019). Analisis Kemampuan Teknik Control, Heading dan Passing Siswa Ekstrakurikuler Futsal SMP Negeri 13 Kota Bengkulu. Kinestetik: Jurnal Ilmiah Pendidikan Jasmani, 3(1), 118-124.

Goff, J. D., \& Crawford, R. (2011). Diagnosis and treatment of plantar fasciitis. American Family Physician, 84(6), pp. 677-682.

Graha, A. S. (2013). Terapi massage cedera olahraga metode Ali Satia Graha (therapy massage sport injury). Jakarta: HAKI Kemenkumham.

Jaya, A. (2008). Futsal: Gaya hidup, peraturan, dan tips-tips permainan. Yogyakarta: Pustaka Timur.

Jaya, A. (2008). Futsal: Gaya Hidup, Peraturan, dan Tips-Tips Permainan. Yogyakarta: Pustaka Timur.

Lhaksana. (2011). Taktik dan strategi futsal modern. Jakarta: Be Champion.

Marhaendro, A.S.D. (2004). Dari futsal menuju sepakbola. Jurnal Olahraga, 10(3), pp. 89-103.

Massy, N. (2016). An unusual presentation of tibialis anterior. International Journal of Anatomycal Variations, 9(1), pp. 1-2.

McCall., A., Carling, C., \& Davison, M. (2015). Injury risk factors, screening tests and preventative strategies: a systematic review of the evidence that underpins the perceptions and practices of 44 football (soccer) teams from various premier leagues. BJSM, 1(1),pp. 1-26.
Setiawan, A. (2011). Faktor timbulnya cedera olahraga. Jurnal Media Ilmu Keolahragaan Indonesia, 1(6), pp. 94-98.

Setiawan, A. (2011). Faktor Timbulnya Cedera Olahraga. Jurnal Media Ilmu Keolahragaan Indonesia, 1, 94-98.

Siswandi, E., Yarmani, Y., \& Sihombing, S. (2018). PENGARUH METODE LATIHAN TEKNIK DISTRIBUSI TERHADAP KETERAMPILAN DRIBBLING ZIG-ZAG PERMAINAN FUTSAL. Kinestetik: Jurnal Ilmiah Pendidikan Jasmani, 2(2), 173-178.

Sugiyono. (2009). Metode Penelitian Pendidikan: Pendekatan Kuantitatif, Kualitatif dan $R \& D$. Bandung: Alfabeta.

Suharjana. (2013). Kebugaran Jasmani. Yogyakarta: Jogja Global Media. 